Original Article

\title{
Open Access Serials: the High Dilution Research case.
}

\author{
Carlos Renato Zacharias (PhD)
}

São Paulo State University, SP, Brazil

\begin{abstract}
Open Access Serials (OAS) seems to be the new tendency in scientific publication and for all society segments. In this article, we are interested in discussing how well an OAS model fits to High Dilution (HD) research. This multidisciplinary area is open to experts from all areas of knowledge, requiring experimental trials and models as well as theoretical approaches. However these researchers must be brought together around a thematic, peer-reviewed and easily accessible serial, able to attain high impact parameters without losing its focus, where theoretical backgrounds and concepts may be presented and actively discussed, ranging from experimental to theoretical approaches, basic to applied researches, also reporting clinical, historical and sociological studies. The features of OAS fit well with the HDs community needs regarding a scientific serial. Also, the electronic support allows to divulgate larger texts and figures, movies, interviews, audio and any other kind of multimedia files. Thus, a scientific OAS devoted to HDs would be very well accepted by the international community.
\end{abstract}

Keywords: open access, high dilution, online serial.

\section{Introduction}

Open Access Serial (OAS) seems to be a new and growing tendency in scientific publication [1-3]. It joins researchers, academicians, librarians, administrators, governments and also the nonscientific community, around the right of changing high quality information, free of charge, full-text and fast access.

OAS can be shortly described as a way to disseminate information in the broadest possible way, free of charge, while ensuring the authors their fundamental rights: the intellectual property and the widest dissemination of theirs ideas. The best vehicle for that in our time is Internet. OAS combines, thus, immediate and wide access.

The quality of available information may be warranted by a peer-review policy, as in conventional scientific journals. However, an electronic OAS transcends the limits of printed media extending its reach to a new level, by making publications available in multi- and hypermedia formats (e.g. texts, images, movies, links) accessible to anyone - a researcher, a politician, a private citizen - anywhere and anytime, without restrictions in reading, download, storage, links, printing, while respecting the author's rights.

Current discussions related to OAS are really important [4], especially because we are talking about freedom and rights of authors, readers and publishers, immersed in a market society. Different communities can converge in different models for publication, especially those involved with military research or resulting in patentable discoveries.

In this article, our interest is to discuss how fitting is an OAS to the High Dilution (HD) research community needs. Would be an OAS adequate to it? What can we expect from the HD research community? What are its particular characteristics, needs and expectations? In short, are OAS fitted to HD research?

\section{What is a HD?}

The most known example of a high dilution is a homeopathic medicine in its liquid form. A HD is produced through a serial process of dilution and shaking, reaching levels where mathematically no more original molecules may be found. This represents the most critical barrier for the scientific community to accept the efficacy of homeopathic medicine.

However, HD is not only homeopathy. Nowadays, HD applications are very common in Agriculture and Veterinary practice [5-12]. Treatments of soil, seeds, plants and animals, preventive or corrective have become a powerful solutions, joining low cost, low chemical contamination, high aggregated value, and ecological management. In such cases, HD uses are based on the principles of isopathy, homotoxicology, biodynamic agriculture, among others. Some of these positive results are based on low quality methodological experiments. However, 
others have been performed according to the current scientific standards and can be found in the scientific literature [13-19].

Laboratory experimental studies have been performed using high diluted drugs and substances in an empirical context, although their theoretical background has not been well established yet. Human clinical practice has collected evidences supporting the existence of pharmacological effects. However, no one yet knows how is the physical structure of a HD nor its mechanism of action.

Thus, HD covers different approaches like homeopathy, hormesis, isopathy, homotoxicology, tautopathy, use of nosodes and biotherapics, in human, veterinarian and agricultural fundamental and applied research.

A working definition for a HD may describe it as a preparation obtained through a serial dilution procedure in such a way that the concentration of the initial active substance becomes lower than the one of substrate contaminants or molecular species. Usually, a HD is prepared in a liquid solvent, but it may also be prepared in a solid one (in a procedure named as trituration). There are some technical rules described in Pharmacopeias and other sources defining standard procedures.

\section{The HD phenomenon and the community.}

The HD phenomenon has been observed since the $18^{\text {th }}$ century from clinical evidences. Nevertheless, a conceptual framework still remains weakly established and no accepted theoretical background has been formulated yet. Thus, this subject remains open to experts from all areas of knowledge, requiring experimental trials and models as well as theoretical approaches. Therefore, an important characteristic of the HD phenomenon is its multidisciplinary approach.

The researchers' community involved in HD is small and disperse when compared to classical areas of knowledge (e.g. medicine, physics, biology), whose members are divided into well established subareas (e.g. cancer, high energy physics, immunology). Also, due to current academic requirements, (e.g. papers published in high impact serials), most HD researchers are also involved in non-HD research, sharing their productive time with traditional areas of research.

A multidisciplinary subject matter without a common theoretical background makes collaboration among researchers ineffective. Without conceptual or practical references, validation procedures cannot be easily implemented and rationales cannot be discussed in depth. Clinical evidences have been essential to prove that the HD phenomenon truly exists and must be studied intensively. However, such evidences cannot explain how the phenomenon operates, its mechanism of action nor its molecular structural features.

Also, the lack of references and the difficulty to promote wide discussions make room to dogmas and opinions, which contribute to feed the HD field with legends and fantasies, far away from any scientific rationality. At the same time, in spite of the lack of scientific background, it has been observed an ever growing interest in $\mathrm{HD}$, including plants applications like pests control, plants health and growing, as well as animals veterinary care. To summarize, HDs have been applied into practice in different fields, although their actions cannot yet be scientifically explained. Moreover, this situation is not due to a lack of experimental evidence, but largely to a difficulty in establishing a common theoretical and conceptual background, and in exchanging information between different groups and areas of investigation, each one with its own technical terms, notions and methods.

\section{HD and Open Access}

The main reason for authors to submit articles for publication is to spread their ideas and efforts in order to exchange them with others researchers. This is the way science has been built and technology has developed. For anyone working within a confined area of investigation, belonging to a specific community, the number of relevant journals is reduced. This allows to put authors and readers efficiently in touch. Conversely, in multidisciplinary areas the number of journals is larger and such a comfortable scenario is not achieved. Moreover, HD research involves experimental, theoretical, historical and sociological approaches and methods. Thus, a multidisciplinary serial joining all these features together would be adequate for the HD community.

As mentioned above, due to current scientific practice, high-impact journals are usually preferred by authors, even when the journal chosen has small significance for HD research. As HD studies can be described as an emergent scientific field, a specific journal addressing its needs is necessary. A disperse, only part-time dedicated to HD research community would greatly benefit from an easy access serial. Regarding this last item, it must be also taken into account the limitation in funds for libraries to subscribe to journals, particularly in developing countries.

For these reasons, the HD community must be brought together around a thematic, peer-reviewed and easily accessible serial, able to reach a high impact parameter without losing its focus, where theoretical backgrounds and concepts may be presented and intensely discussed, ranging from experimental to theoretical approaches, basic to applied researches, also reporting clinical, historical and sociological works. 
An excellent solution would be the OAS model. OAS are easy accessible to any Internet user, supplying free and full-text online access. Developing countries would also benefit at no cost, authors would see their papers increasingly read, and taxpayers would be respected in their right to access the results of what they have funded. Beyond the research community and academic circles, all citizens would be able to become readers, favoring government agents, policy-makers, journalists, professionals and hobbyists.

For those authors involved with military research, private sponsoring or involved with patentable discoveries, whose public divulgation can be restricted, OAS does not represent any disadvantage regarding restricted journals.

Language barriers also constitute an important problem to deal with. While English has emerged as the conventional language of science, it still excludes many readers and authors. Multilingual translations are impossible for printed serials due to costs, which is an irrelevant issue to online serials. On the other hand, the latter can very easily deal with infrastructure to support multilingual versions of a same text.

To conclude, any scientific serial must fulfill certain quality criteria: peer-review is still considered the best resource to warrant quality in both printed and online serials.

\section{Conclusions}

The features of OAS fit well with the HD research community requirements for a scientific serial: free, immediate and full access to peer-reviewed articles, availability in many languages, dealing with multidisciplinary views and different approaches and methods, with high readability and research impact. Also, electronic support allows to divulgate larger texts an figures, movies, interviews, audio and any other kind of multimedia files.

In a serial devoted to the science of HD, the editorial board must assume the compromise and responsibility to keep the paper's quality as high as possible. This point is not so critical in a well established area, but is HD, where theoretical and conceptual backgrounds are not yet well defined, the possibility of ideological and subjective positions is high. So, compromise among high quality cutoff criteria in order to filter inadequate papers and an opening to new theoretical propositions or challenging ideas in order to facilitate new insights and fructiferous discussions, must be carefully implemented by editors and reviewers. Provided these requirements are met, an OAS devoted to High Dilutions would be very well accepted by the international community.

\section{References}

[1] Budapest Open Access Initiative. Budapest: Open Society Institute; 2001 [updated 2002 Feb 14; cited 2008 Apr 14]. Available from:

http://www.soros.org/ openaccess/read.shtml.

[2] Bethesda Statement on Open Access Publishing. Maryland; Earlham College; 2003 [updated 2003 Jun 20; cited 2008 Apr 14]. Available from: http://www.earlham.edu/ peters/fos/bethesda.htm\#s ummary.

[3] Berlin Declaration on Open Access to knowledge in the Sciences and Humanities. Berlin; Open Access to Knowledge in the Sciences and Humanities; 2003 [updated Oct 22; cited 2008 Apr 14]. Available from: http://oa.mpg.de/openaccessberlin/berlindeclaration.html.

[4] Open Access Overview. Peter Suber; Earlham College; 2006 [updated Jun 21; cited 2008 Apr 14]. Available from: http://www.earlham.edu/ peters/fos/overview.htm.

[5] Lobreiro J. Homeopathic treatment for infertility in a prize Nelore bull. Homeopathy. 2007; 96(1): 4951.

[6]Bonato CM. Homeopathy in Vegetal Models. Cultura Homeopática. 2007; 6(21): 24-28.

[7] Bonfim FPG, Martins ER, Dores RGR, Barbosa CKR, Casali VWD, Honório ICG. Use of homeopathic Arnica montana for the issuance of roots of Rosmarinus officinalis L. and Lippia alba (Mill) N.E.Br. Int J High Dil Res [online]. 2008 [cited 2008 Apr 14]: 7(23); 113-117. Available from: http://www.feg.unesp.br/ ojs/index.php/ijhdr/article/ view/276/348.

[8] Marques RM, Marques-Silva GG, Bonato CM. Effects of high dilutions of Cymbopogon winterianus Jowitt (citronella) on the germination and growth of seedlings of Sida rhombifolia. Int J High Dil Res [online]. 2008 [cited 2008 Apr 14]; 7(22):31-35. Available from:

http://www.feg.unesp.br/ ojs/index.php/ijhdr/article/ view/208/342.

[9] Silva NL, Moletta JL, Minho AP, Filippsen LF. Use of biotherapic in the control of natural infestation by Boophilus microplus: pilot study. Int J High Dil Res [online]. 2008 [cited 2008 Apr 14]; 7(22): 36-38. Available from:

http://www.feg.unesp.br/ ojs/index.php/ijhdr/article/ view/251/337.

[10] Barzon CD, Medeiros F, Moraes RE, Silva LCM, Massambani C, Takemura OS, Gazim ZC. Preliminary study of homeopathic treatment of subclinical mastitis evaluated through somatic cells count and California mastitis test. Int J High Dil Res [online]. 2008 [cited 2008 Apr 14]; 7(24): 147- 
151. Available from:

http://www.feg.unesp.br/ ojs/index.php/ijhdr/article/ view/292/364.

[11] Ferreira MIC, Pinto LF. Homeopathic treatment of vaginal leiomyoma in a dog: case report. Int J High Dil Res [online]. 2008 [cited 2008 Apr 14]; 7(24):152-158. Available from: http://www.feg.unesp.br/ ojs/index.php/ijhdr/article/ view/304/358.

[12] Zacharias F, Guimarães JE, Araújo RR, Almeida MAO, Ayres MCC, Bavia ME, MendonçaLima FW. Effect of homeopathic medicines on helminth parasitism and resistance of Haemonchus contortus infected sheep. Homeopathy. 2008; 97(3): 145-15.

[13] Bastide M, Daurat V, Doucet-Jabeuf M, Pelegrin A, Dorfman P. Immunomodulator activity of very low doses of thymulin in mice. Int $\mathrm{J}$ Immunotherapy. 1987; 3(3): 191-200.

[14] Youbicier-Simo BJ, Boudard F, Mékaouche M, Baylé JD, Bastide M. A role for Bursa Fabricii and bursin in the ontogeny of pineal biosynthetic activity in chicken. J Pineal Res. 1996; 21(1): 35-43.
[15] Linde K, Melchart D. Randomized controlled trials of individualized homeopathy: a state-of-theart review. J Altern Complement Med. 1998; 4(4): 371-388.

[16] Belon P, Cumps J, Ennis M, Mannaioni PF, Roberfroid M, Sainte-Laudy, J. et al. Histamine dilutions modulate basophil activation. Inflamm Res. 2004; 53: 181-188.

[17] Bastide M. Interpretative theories about ultradilutions: supporting evidences. XX Symposium of GIRI, Annals. Cultura Homeopática. 2006; 5(16): 2230 .

[18] Bonamin LV. Experimental data supporting interpretative theories for high dilutions: tribute to Madeleine Bastide. Cultura Homeopática. 2007; 6(21): 29-35.

[19] Dantas, F, Fisher P, Walach H, Wieland F. Rastogi DP, Teixeira H, et al. A systematic review of the quality of homeopathic pathogenetic trials published from 1945 to 1995. Homeopathy. 2007; 96(1): 4-16.

\section{(c)) BY-NC-ND Licensed to GIRI}

Support: author declares that this study received no funding

Conflict of interest: the author is the Editor-in-Chief of the International Journal of High Dilution Research.

Received: 16 April 2008; Revised: 30 August 2008; Published: 15 September 2008

Erratum: 30 Dec 2008. (http://www.feg.unesp.br/ ojs/zacha_ijhdr/erratum/?v=7\&i=24\&pi=159)

Correspondence author: Carlos Renato Zacharias, zacha@feg.unesp.br

How to cite this article: Zacharias CR. Open Access Serials: the High Dilution Research case. Int J High Dilution Res [online]. 2008 [cited YYYY Mmm DD]; 7(24): 159-162. Available from:

http://www.feg.unesp.br/ ojs/index.php/ijhdr/article/view/267/359. 